\title{
Empreendedorismo como Prática: Empreendedorismo Cultural na Prática Festiva do Pagode Baiano
}

\section{Entrepreneurship as Practice: Cultural Entrepreneurship in the Festive Practice of Ba- hia's Pagode}

\author{
Simony Rodrigues Marins \\ Universidade Federal da Bahia - UFBA - Brasil \\ simonymarins@gmail.com \\ ORCID: 0000-0003-3881-1194 \\ Eduardo Paes Barreto Davel \\ Universidade Federal da Bahia - UFBA - Brasil \\ davel.eduardo@gmail.com \\ ORCID: 0000-0003-0610-6474
}

Submetido em 28/11/2018; Aprovado em 21/06/2019

\begin{abstract}
Resumo:
Marcado tradicionalmente pelo positivismo e individualismo metodológico, o empreendedorismo vem sendo, recentemente, repensado e ampliado teoricamente. Uma das lentes usadas para esta ampliação é a da epistemologia da prática. Apesar dos estudos baseados em prática serem ativos em diversos temas da Administração (aprendizagem, liderança, estratégia), ainda permanecem restritos quando o assunto é empreendedorismo. 0 objetivo desta pesquisa é ampliar, consolidar e discutir a compreensão do empreendedorismo a partir dos estudos baseados em prática. Empiricamente, focamos no empreendedorismo cultural do setor musical. A metodologia da pesquisa apoia-se em uma abordagem qualitativa para investigar uma experiência de empreendedorismo musical do pagode na Bahia. Como contribuição, uma concepção integrada do empreendedorismo como prática é elaborada e discutida.
\end{abstract}

Palavras-Chave: Empreendedorismo. Empreendedorismo cultural. Prática. Música popular.

\begin{abstract}
:
Traditionally oriented by positivism and methodological individualism, entrepreneurship begins to be theoretically challenged in recent times. One of the lenses used for this challenge is the epistemology of practice. Although the practice-based studies are active in several research fields of the Management (learning, leadership, strategy), they remain limited in terms of the field of entrepreneurship. The purpose of this research is to enlarge, consolidate and discuss the understanding of entrepreneurship from the practice-based studies. Empirically, we focus on the cultural entrepreneurship of the music industry. The methodology is based on a qualitative research in order to investigate a musical entrepreneurship experience of the pagode (musical style) in Bahia. As a contribution, the conception of entrepreneurship as a practice is proposed and discussed.
\end{abstract}

Keywords: Entrepreneurship. Cultural entrepreneurship. Practice. Popular music.

\section{Introdução}

Campo fragmentado de pesquisas (Busenitz et al., 2014; Shane \& Venkataraman, 2001; Schildt, Zahra \& Sillanpaa, 2006), o empreendedorismo assenta-se em variadas dimensões, temas e perspectivas. Todavia, carecemos de uma concepção teórica mais radical (Busenitz et al., 2003; Busenitz et al., 2014; Vale, 2014) e vanguardista do empreendedorismo. As perspectivas existentes se aglomeram em torno de questões como o relacionamento entre ambiente-organização, oportunidades, indivíduos e equipes (Busenitz et al., 2014). Dentro de um campo de pesquisas marcado, tradicionalmente, por teorias positivistas, pressupostos instrumentais, individualismo metodológico (De Clerk \& Voronov, 2009; Johannisson, 2011; Steyaert, 2007) e lógicas economicistas (Davel \& Cora, 2016), só recentemente, que outras perspectivas emergem como promissoras para o estudo do empreendedorismo (Steyaert, 2007).

Ainda que de forma restrita (Gartner et al., 2016; Johannisson, 2011; Steyaert 2007; Watson, 2013), a perspectiva da prática emerge e busca contribuir com uma melhor compreensão da atividade 
de empreender na relação entre indivíduos e contexto (Watson, 2013), na integração de questões diversas (e.g. o processo, o quê, onde e por que empreender, conforme Gartner et al., 2016). Trata-se de uma perspectiva que se apoia na epistemologia da prática (Cook \& Brown, 1999). Assim, a perspectiva da prática - denominada de Estudos Baseados em Prática (EBP) no campo dos Estudos Organizacionais aparece ainda de forma tímida como um caminho para aprimorar a compreensão do empreendedorismo.

Por seu grau de profundidade na análise social, de orientação sociológica e ancoragem na virada prática (Schatzki, Knorr-Cetina \& Von Savigny, 2001), a perspectiva do empreendedorismo como prática desponta como um meio de proporcionar uma visão ontológica, epistemológica e metodológica diferenciada (Johannisson, 2011; Steyaert, 2007) para os estudos do empreendedorismo. Ao invés de métodos post hocs (Busenitz et al., 2003), os EBP fomentam métodos de pesquisa que vão além do estudo de questões pontuais (Busenitz et al., 2003) para considerar a integração de várias concepções e dimensões. Ao mobilizarmos os EBP na análise do empreendedorismo, ampliamos radicalmente as visões sobre o fenômeno, com possibilidades de deslocá-lo de uma visão estática e linear, pois a tendência seria integrar dimensões subjetivas, sociais, políticas, institucionais, narrativas, contextuais, processuais e sensíveis, para alcançar uma compreensão mais complexa e completa do empreendedorismo.

Em revanche, as pesquisas sobre o empreendedorismo como prática encontram-se restritas a um processo embrionário (De Clerk \& Voronov, 2009; Gartner et al., 2016; Goss et al., 2011; Johannisson, 2011; Vogt, Bulgacov \& Elias, 2019; Watson, 2013; Terjesen \& Elam, 2009), apesar dos EBP serem ativos em diversos temas da Administração (aprendizagem, liderança, estratégia). No Brasil, essa restrição é mais dramática (Borges, Brito \& Lima, 2016, Borges; Lima \& Silvestre, 2018), com poucas pesquisas de caráter empírico (Vogt \& Bulgacov, 2018). Nesta pesquisa, buscamos reduzir essa restrição. 0 objetivo de nossa pesquisa é ampliar, consolidar e discutir a compreensão do empreendedorismo a partir dos EBP e a partir de uma pesquisa empírica. Para alcançar esse objetivo, dispomos de um arranjo teórico e metodológico. No arranjo teórico revisamos os raros estudos sobre empreendedorismo como prática e aprofundamos o vínculo entre o empreendedorismo cultural e os EBP. Empiricamente, investigamos a prática do empreendedorismo da música popular do pagode no setor musical.

O empreendedorismo cultural é pouco estudado (Davel \& Cora, 2016), entretanto, é considerado como um alicerce para se pensar a economia cultural e criativa (Henry \& Bruin, 2011; Hartley et al., 2015; Jones et al., 2015; Khaire, 2017), que depende de atividades empreendedoras dentro de um fluxo contínuo. Trata-se de atividades que são estruturais dos avanços e distinções culturais de uma sociedade, resolvendo questões de tradição-inovação, de arte-comércio, de valor simbólico, dentre outros assuntos inevitáveis para o desenvolvimento cultural e criativo de uma sociedade (Ellmeier, 2003; Klamer, 2011). Dentro do campo do empreendedorismo cultural, a atividade musical se destaca por sua representatividade social, local, popular, cultural e mercadológica (Baia, 2011), além de ser fortalecida territorialmente por meio de condições que propiciem seu florescimento (Frith, Cloonan \& Williamson, 2009). 0 Brasil é reconhecido pela sua marca de 'musical' e Salvador (Bahia) pelo seu título de 'cidade da música' (conferido pela UNESCO, 2016). Na Bahia, o pagode é um estilo musical predominante por sua efervescência no cotidiano das comunidades, pelas controvérsias que suscita e pelas variações estilísticas que permite, contribuindo com formas de adquirir, armazenar e transferir conhecimento. É um estilo repleto de práticas empreendedoras pautadas pela criatividade e inovação cultural.

Os resultados dessa pesquisa buscam contribuir para ampliar, consolidar e discutir a compreensão do empreendedorismo a partir dos EBP e a partir de uma pesquisa empírica junto ao empreendedorismo musical do pagode do grupo Harmonia do Samba. A comunhão entre teoria (articulação entre os EBP e os estudos sobre empreendedorismo) e a campo empírico (prática empreendedora na cultura musical) nos permitiu entender o carater relacional de práticas identitárias, estéticas e políticas que imbricam-se na criação e na inovação cultural necessária ao empreendedorismo como prática no campo cultural.

\section{Empreendedorismo e Prática: Conexões Preliminares}

Ao se questionar sobre a diferença entre o fazer empreendedor e o ser empreendedor (Gartner, 1988), os pesquisadores abriram caminhos para expandir a visão do empreendedorismo. 0 conceito do empreendedorismo como prática (Gartner et al., 2016; Johannisson, 2011; Steyaert, 2007) apresentase atrelado à virada prática (Schatzki, Knorr-Cetina \& Von Savigny, 2001) nas Ciências Sociais, sendo, assim, uma nova perspectiva para decodificar o processo de empreender (Gartner, et al., 2016; Steyaert, 
2007). Os EBP têm ganhado destaque nos Estudos Organizacionais, principalmente por proporcionarem análises complexas (Corradi, Gherardi \& Verzelloni, 2010), alternativas às visões lineares e racionalistas no campo da Administração (Gherardi, 2006). Mesmo dispondo de diversificadas correntes epistemológicas (Nicolini, Gherardi \& Yanow, 2003), os EBP evitam dualismos e concebem as práticas como produtoras da sociedade e das organizações (Feldman \& Orlikowski, 2011; Schatzki, 2006).

Uma orientação para a prática do processo empreendedor pode gerar muitas possibilidades para a pesquisa da práxis da teorização social no campo (Steyaert, 2007). Novas visões podem contribuir para conceber o processo empreendedor como uma conquista cultural, conectada à experiência vivida e às forças culturais, políticas e sociais (Steyaert, 2007). Por enfocar os esforços de colaboração (Johannisson, 2011), concebe-se a atividade de empreender como um empreendimento existencial na criação de uma identidade. Tem-se uma base de valor que extrapola a ação instrumental - visão estrita direcionada a um mercado competitivo fixado, exclusivamente, no aspecto econômico - para ampliar e estimular o desenvolvimento de uma visão mais complexa do processo de empreender.

Frente à diversidade de definições, podemos definir a prática como "um modo relativamente estável no tempo e socialmente reconhecido de ordenar elementos heterogêneos em um conjunto coerente" (Gherardi, 2006, p.34). A prática pode ser caracterizada por: (a) o significado e reconhecimento de um grupo de atividades enquanto unidade (conjunto); (b) o tempo enquanto ações situadas; (c) o reconhecimento social e (d) um modo de organização de mundo (Gherardi, 2006). São saberes relacionados a dada atividade em meio a um compartilhamento de visões (Schatzki, Knorr-Cetina \& Von Savigny, 2001).

Como 'maneiras de fazer' contidas em um conjunto de procedimentos de delimitação complexa, as práticas possuem uma "natureza estética, ética e prática no saber-fazer cotidiano" (Certeau, 2013, p.138). Elas podem tanto confrontar criativamente espaços ou ordens, mudando lógicas racionalizantes (táticas) ou ainda criar ou seguir ordens dominantes por meio de poder (estratégias), havendo um caráter político no cotidiano (Certeau, 2013). São formas vivenciadas de improvisar que repercutem em diferentes saberes cotidianos adaptativos e provisórios (Certeau, 2013; Orlikowski, 2002). São práticas que pressupõem a capacidade de entender o que as compõe, bem como as regras que as orientam, combinadas a aspectos teleológicos e afetivos, incluindo uma compreensão geral sobre a natureza do próprio fazer (Schatzki, 2006). São atividades organizadas, com um início e fim marcados como as práticas políticas, educacionais, gerenciais ou operacionais (Schatzki, 2006).

0 empreendedorismo como prática prevê que as ações fazem parte de um cotidiano empreendedor, estruturadas por diferentes maneiras de praticar o empreendedorismo, considerado como um meio de alcançar outras formas e sentidos de vida (Davel \& Cora, 2016). Assim, o foco recai no cotidiano do empreendedorismo como unidade de análise e como um tipo particular de atividade humana (Watson, 2013). Outras influências do empreendedorismo como prática advêm do estudo pragmático da efetuação de Sarasvathy (2001). Embora o estudo da efetuação trate de esquemas de causalidade, confere relevância aos meios disponíveis para que a ação empreendedora aconteça na busca de finalidades (Watson, 2013). A atenção se concentra tanto no ser empreendedor, no seu saber, quanto nas suas relações, aceitando e lidando com as ocasiões de forma flexível (Sarasvathy, 2001; Watson, 2013). Como pertinentes a uma orientação pragmática da realidade, estes estudos são apontados (Steyaert, 2007) como influências para conceber o fenômeno do empreender de forma menos individualizada.

Estudos de empreendedorismo buscam, por exemplo, descobrir como surgem oportunidades, como são ou não captadas, a influência de redes, a interferência do tempo, as análises de riscos (Busenitz et al., 2014). Colocam-se diferentes lentes para estes e outros fatores, tendo em vista à compreensão da natureza cotidiana e socialmente construída do fenômeno (Feldman \& Orlikowski, 2011), o reconhecimento da prática, de ferramentas e métodos utilizados, o relacionamento e integração com as cognições, comportamentos e habilidades dos empreendedores, o relacionamento com o contexto da organização (Gartner et al., 2016; Johannisson, 2011), com a criatividade (Steyaert, 2007) e suas diferentes finalidades (Davel \& Cora, 2016).

O empreendedorismo como prática pode ser apreendido como uma forma de perceber a existência de irracionalidades, sentimentos e emoções (e.g. paixão, imediatismo e improvisação, conforme Hjorth et al., 2003) para além de resultados econômicos e da visão do empreendedorismo como algo intencional e planejado. A constituição de padrões de comportamento, formas de compreender, saber e desejar são elementos e qualidades do empreendedorismo que estão vinculadas a questões individuais, coletivas e espaciais (Gartner et al., 2016). 0 acesso ao capital cultural e simbólico molda habilidades 
que geram legitimidade para a resolução de conflitos (De Clerk \& Voronov, 2009). 0 empreendedorismo acontece no âmbito das práticas cotidianas, cujo conhecimento tácito e o relacionamento são relevantes para desenvolver organizações e sociedade de forma criativa e oportuna (Certeau, 2013; Johannisson, 2011). Não concebemos o empreendedorismo a partir de uma postura estereotipada ou heroica, mas como atividades do cotidiano feitas por meio de processos socioculturais (Steyaert \& Katz, 2004; De Clerk \& Voronov, 2009). Pelo contrário, falamos de um fenômeno complexo que considera tanto indivíduo quanto relações sociais, contexto, ambiente e história. Por isso, precisamos entender como o empreendedorismo acontece no processo da prática, em diversas etapas da vida organizacional (Watson, 2013).

\section{Empreendedorismo Cultural e o Campo Cultural da Música}

Dentro do emergente campo de estudos sobre empreendedorismo cultural (Davel \& Cora, 2016; Guerra \& Paiva Júnior, 2014; Paiva Júnior et al., 2012), consideramos este fenômeno como a ação empreendedora no espaço cultural e artístico. Considerado como essencial no contexto da economia cultural e criativa (Henry \& Bruin, 2011; Hartley et al., 2015; Jones et al., 2015; Khaire, 2017), o empreendedorismo cultural depende de atividades empreendedoras incessantes. Repleto de singularidades (Banks et al., 2000; Banks; Gill \& Taylor, 2014; Klamer, 2011), o empreendedorismo cultural relaciona-se intrinsecamente à uma prática cultural, artística e criativa, sem evacuar a dimensão econômica.

Com a importância crescente dos setores e atividades culturais para as economias contemporâneas, a mudança em curso entre um tipo de economia orientada pela produção para uma economia voltada para o consumo destaca a relevância dos bens culturais, criativos e artísticos (Ellmeier, 2003; Lash \& Urry, 1994). Tradicionalmente, o empreendedorismo fortaleceria ideais neoliberais na cultura, em uma economização da cultura, dentre outros impactos advindos da falta de organização política para esta nova categorização do trabalho como o trabalho empreendedor (Ellmeier, 2003). Nesta contemporaneidade, é ainda mais acirrado o acaloramento entre economia e cultura, sendo pelo viés da ambivalência ou da complementaridade, conforme promovem as políticas culturais, no contexto da economia criativa e cultural (Ellmeier, 2003).

Em uma análise mais ampla, esta discussão pode representar contextos complexos de confronto entre racionalidades. A racionalidade instrumental, representada pela visão econômica formalista e a imbricação de fundamentos gerenciais na sociedade, pode ser confrontada à racionalidade substantiva, representada pela busca de valores, éticas (Guerreiro Ramos, 1989; Polanyi, 2012) e estéticas. São vários tipos de vínculos culturais, criativos e artísticos que sustentam o empreendedorismo cultural (Klamer, 2011; Preece, 2011; Lingo \& Teeper, 2013). Os vínculos criativos, por exemplo, são vistos como um atributo moral (Klamer, 2011) nesse processo. Assim, a produção de bens e serviços está relacionada à valores culturais e artísticos, com sua riqueza atribuída aos significados e símbolos (Banks et al., 2000).

Neste contexto, o artista, como um núcleo da criação cultural, é cada vez mais instigado a se pensar como empreendedor (Bureau \& Zander, 2014; Lindqvist, 2011; Rentschler, 2007; Scherdin \& Zander, 2011), tendo em vista a chegada incisiva da lógica empreendedora tradicional no mundo cultural, mesmo pela mudança na postura de políticas públicas, antes financiadora da cultura, mas agora estimuladora do empreendedorismo para a autossuficiência da cultura (Ellmeier, 2003). No empreendedorismo artístico (Bureau \& Zander, 2014; Scherdin \& Zander, 2011), o artista se adapta para atender, em seu cotidiano de práticas, às novas demandas, perspectivas (Rentschler, 2007) e transformações tecnológicas (Ellmeier, 2003). Deve-se atentar às condições para que subjetividades artísticas (Scherdin \& Zander, 2011) floresçam como compartilhamentos e redes de relacionamentos, oportunidades de trabalho e espaços criativos de produção (Frith, Cloonan \& Williamson, 2009).

Para adentrar o campo de estudos em empreendedorismo cultural, é necessário adotar posturas epistemológicas capazes de lidar com essas singularidades. Por isso, constatamos a importância da epistemologia da prática. Como campo emergente, as pesquisas sobre empreendedorismo cultural, devem se desprender da ortodoxia teórica para conseguir considerar plenamente e coerentemente essas singularidades. Como um campo marcado por dinâmicas subjetivas e ainda pouco explorado teórica e organizacionalmente, os EBP proporcionam formas de valorizar essas singularidades do empreendedorismo cultural.

Dentro do campo do empreendedorismo cultural, a atividade musical se destaca por sua representatividade social, local, popular, cultural e mercadológica (Baia, 2011), além de ser fortalecida, territorialmente, por meio de condições que propiciem seu florescimento (Frith, Cloonan \& Williamson, 
2009). O Brasil é reconhecido pela sua marca de 'musical' e Salvador pelo seu título de 'cidade da música' (conferido pela UNESCO, 2016). No campo musical, o sucesso comercial vincula-se à existência de pessoas que fazem música por paixão (Frith, Cloonan \& Williamson, 2009), revelando o quanto o empreendedorismo depende de forças subjetivas para além da racionalidade puramente econômica. Por exemplo, é comum reconhecer que habilidades devem ser combinadas em equipe, pertencendo a uma comunidade criativa mais ampla, dentro de uma tensão constante entre rivalidade e competição, entre cooperação e colaboração (Wilson \& Stokes, 2002). Além disso, um estilo musical pode apresentar divergências quanto à sua estética e apreciação popular, mesmo que existam ações ou inovações que perpetuam um estilo musical.

Na Bahia, o pagode é um estilo musical predominante por sua efervescência no cotidiano das comunidades, pelas controvérsias que suscita e pelas variações estilísticas que permite, contribuindo com formas de adquirir, armazenar e transferir conhecimento. É um estilo repleto de práticas empreendedoras pautadas pela criatividade e inovação cultural. 0 pagode é central nos fazeres e sociabilidades do cotidiano popular de Salvador, gerando polêmicas (Chagas, 2016; Leme, 2003; Moura, 1996) e um imaginário repleto de estereótipos e estigmas (Souza, 2015). Trata-se de uma música popular e midiática (Castro, 2011; Oliveira \& Campos, 2016) com forte adesão popular e presença decisiva na indústria cultural musical na Bahia (Chagas, 2016). No contexto de visibilidade da cultura baiana, o pagode alimenta uma variedade de fazeres empreendedores, organizacionais (Chagas, 2016; Leme, 2003; Moura, 1996) e festivos. O pagode representa um tipo de indústria cultural enraizada na cultura popular e altamente polêmica, que permanece inexplorada do ponto de vista organizacional e empreendedor.

\section{Empreendedorismo Cultural Musical na Bahia: A Prática Festiva de um Grupo de Pagode}

\subsection{Metodologia de Pesquisa}

Tendo como objetivo ampliar, consolidar e discutir a compreensão do empreendedorismo como prática, realizamos uma pesquisa qualitativa e exploratória, fundamentada na observação sistemática de práticas que se relacionam ao empreendedorismo de um grupo musical em uma de suas festas. Inicialmente, buscou-se entender o histórico de práticas do grupo musical. Em um segundo momento, focouse na prática festiva do grupo. A música convida a festa, que se traduz aqui em um conjunto dos ensaios de verão da capital baiana, que começam no segundo semestre de cada ano. 0 ensaio é uma prática festiva recorrente que faz parte também das práticas de grupos de pagode em Salvador. 0 ensaio ou o show de pagode é uma festa que requer organização, planejamento econômico e cuidado artístico.

Um dos grupos de pagode mais destacados na Bahia é o Harmonia do Samba, escolhido pela sua representatividade (admirado localmente e nacionalmente) e conveniência (acesso ao produtor do grupo). Completando 26 anos de existência em 2019, o grupo apresentou inovações, mesmo mantendo características importantes do movimento do pagode (Chagas, 2016). Como parte da história do Harmonia do Samba, o ensaio "A Melhor Segunda-feira do Mundo" (AMSM) foi iniciado em 2002 e completa em 2019, 17 anos de existência. É uma festa bem-sucedida no universo do pagode baiano.

No primeiro momento da pesquisa, a análise documental foi essencial para entender a história do grupo e suas práticas. Foram levantados, selecionados e analisados documentos de vários tipos sobre o grupo musical e seu ambiente: narrativas midiáticas (reportagens, entrevistas, em TV, rádio, Internet, redes sociais, jornais, revistas) e acadêmicas (artigos, dissertações, teses, livros). A análise dessas narrativas históricas auxiliou um dos pesquisadores na realização da atividade de campo, no segundo momento da pesquisa. A relação com o material empírico foi realizada pela primeira autora deste artigo, apesar de todo material ter sido analisado e interpretado, reflexivamente, pelos dois autores. Nenhum dos autores possuía familiaridade com o universo cultural e organizacional do pagode na Bahia, antes de realizar essa pesquisa.

No segundo momento da pesquisa, o foco recaiu nos ensaios abertos do grupo musical, que ocorrem nas segundas-feiras. Com o auxílio de uma produtora local, também informante do estudo, consegue-se acesso à festa e demais informantes da produção e do grupo. Depois, a partir de uma lógica de bola de neve, outros informantes foram surgindo e contribuindo para o aprofundamento da pesquisa. 0 marco do acesso se deu com a autorização, viabilizada pelo produtor do grupo, de um acesso à pesquisadora como profissional de imprensa, possibilitando circulação quase irrestrita em todo o evento. 
Durante o ensaio, a interação com o material empírico ocorreu por meio de observação sistemática, documentos e entrevistas semiestruturadas. Os documentos e as entrevistas ajudaram a contextualizar e complementar as informações obtidas por meio da observação. Ocorrida em um dia de ensaio, a observação focou nos ditos, não ditos, interações, tempo e espaço, coreografia corporal, ferramentas e artefatos, interesses, tensões, a partir da lógica do zoom in e zoom out (Nicolini, 2009). A pesquisadora contemplou o cenário e contexto externo ao evento e de acesso ao público, o cenário do evento e de seu back stage (área interna ao palco e de acesso aos camarins). Foi acompanhado durante a observação, o início do evento, marcado pela ação de empresas apoiadoras e pela apresentação de artistas convidados, a interação do vocalista do grupo com a imprensa no camarim e a própria apresentação do grupo e convidados, a principal e última parte do evento. A observação incluiu entrevistas realizadas pela mídia junto ao artista, bem como toda a sua interação com os agentes da mídia. Foram realizadas três entrevistas semiestruturadas junto aos produtores do grupo musical e três entrevistas semiestruturadas junto ao público. A análise de documentos envolveu vídeos e fotos de entrevistas que o vocalista forneceu à imprensa em seu camarim antes da apresentação. Documentos publicados na mídia e nas redes sociais relacionadas ao evento foram também analisados.

O material empírico é constituído de narrativas e interpretado a partir da abordagem de análise de narrativas (Gubrium \& Holstein, 2009; Maitlis, 2012; Riessman, 2008; Van Maanen, 1988). As narrativas consideram dados visuais, entrevistas semiestruturadas e registros bibliográficos e documentos que partem de notícias, redes sociais, websites e outros dados públicos com relação ao grupo musical.

Durante a análise, três narrativas de práticas emergiram como centrais, revelando as dimensões artístico-culturais e econômicas da prática empreendedora: (a) narrativa da história empreendedora do grupo; (b) narrativa do contexto das práticas festivas dos ensaios de verão em Salvador; e (c) narrativa da prática festiva da AMSM. Estas narrativas de práticas são analisadas em relação a diversas preocupações conceituais: tempo, espaço, relações e reconhecimento do grupo social, estilos de ação e padrões de comportamento (políticas, éticas, estéticas), premissas, pressupostos e objetivos, a constância ou inconstância das práticas (caráter de permanência ou mudança, planejamento, imediatismo e improvisação), as tensões e controvérsias, interações simbólicas com não humanos, fatores identitários, conhecimentos, formas de compreender, saber e sentir.

\subsection{História Empreendedora do Grupo}

As relações de fundação. 0 surgimento do grupo Harmonia do Samba envolve relações com familiares, com o bairro e com o público. Sobre às relações familiares, a formação do grupo acontece em 1993 quando o baterista Roque Cézar faz um convite à amigos, vizinhos e familiares para constituir o grupo (Website, Letras, 201911). 0 apoio da mãe de Roque foi fundamental, tendo sua importância associada aos recursos iniciais (instrumentos, espaço de ensaios), coesão e organização do grupo², tornandose, posteriormente empresária (Websites, Carnaxe, 2019; Ibahia, 2018). Com o passar do tempo, foram sendo integrados novos participantes e funções. Em 1997, além de Roque na bateria, tem-se o vocalista e dançarino Xanddy, além de nomes como Deco (cavaquinho), Mestre Bimba (baixo, vindo a se tornar o diretor musical), Boca (trompete) e outros (Website, Letras, 201933). Há diferentes protagonismos desempenhados pelos integrantes em diferentes momentos da formação, como a entrada do vocalista Xanddy, que marca nova fase para o grupo. Xanddy explica que, apesar da maior procura da mídia pela figura do cantor, o sucesso do grupo se dá por sua cumplicidade e igualdade dentro de uma equipe unida (Website, Pagode Salvador, 20094). No início, os ensaios ocorriam nos espaços familiares do grupo (como a rua da Glória) no bairro de Capelinha de São Caetano (Website, Carnaxe, 2019) (Figura 1).

Laços são explícitos no discurso do grupo em diversos momentos de sua narrativa por meio da palavra família (por exemplo: "Família Harmonia") e no discurso de fãs (denominados de "a torcida") que evidenciam memória (leva ao passado) afetiva (carregada de sentimentos de vínculos sociomateriais: pessoas, bairros, sons, visões, sentidos) relacionada aos shows nesta fase inicial da carreira do

1 Letras, 2019. Disponível em: https://www.letras.com.br/biografia/harmonia-do-samba. Acessado em: 10/06/2019.

2 Ibahia, 2018. Disponível em: https://www.ibahia.com/detalhe/noticia/especial-20-anos-do-harmonia-conheca-a-historiapor-tras-da-maior-banda-de-pagode-da-bahia/. Acessado em: 2/08/2018.

3 Carnaxe, 2019. Disponível em: http://www.carnaxe.com.br/history/busca/harmoniadosamba.htm Acessado em: $10 / 06 / 2019$.

4 Pagode Salvador, 2009. Disponível e: http://pagodesalvador.blogspot.com/2009/12/biografia-de-harmonia-do-samba.html. Acessado em: 10/06/2019. 
grupo (Diário de campo, 2018). Assim, os laços de amizade e familiaridade alimentados no contexto do bairro imprimiram um aspecto de vizinhança à natureza destas relações. Estes aspectos constituem traços distintivos do grupo; são aspectos que se relacionam e vão compondo uma identidade estética e conformam práticas estéticas empreendedoras (à medida que são constantemente acessadas e usadas) em seu cotidiano artístico.

Figura 1: Vídeo "Respeite”

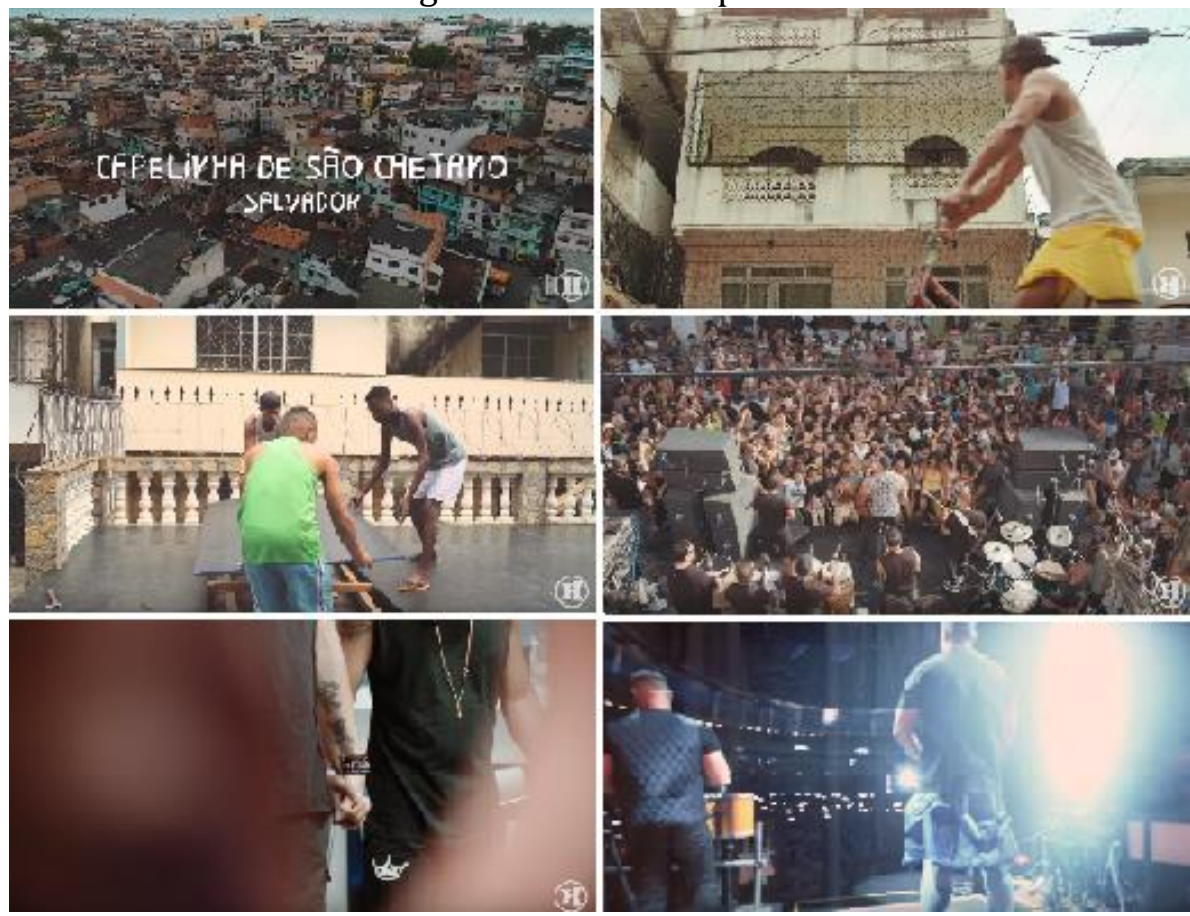

Fonte: Website, You tube - Harmonia do Samba, 2018

Inovação cultural e seu contexto. Tido como paradigmático no estilo do pagode, inicialmente, o grupo teria marcado uma transição no gênero entre uma primeira fase (décadas de 1980 e 1990) para uma segunda fase (décadas de 1990 e 2000) (Chagas, 2016). Nesta narrativa, destaca-se a entrada do vocalista e dançarino Xanddy (1997), trazendo uma diversidade de performances. Com o tempo, Xanddy foi reconhecido como improvisador e líder no entretenimento do público (Website, Cultura Mix ${ }^{5}, 2016$ ) por sua irreverência e cumplicidade chamando com carisma e sensualidade a participação do público durante os shows (Website, Pagode Salvador, 2019). Com isto, o grupo diferenciou o uso de dançarinas/os e este formato teria sido seguido por outros grupos de pagode (Chagas, 2016). As roupas se aproximavam do perfil do público, com um perfil mais casual, diferentemente de grupos de pagode de anos anteriores (Chagas, 2016). Musicalmente, outras inovações de estilo foram aparecendo nos anos 2000, com a inserção e integração de novos instrumentos e que geraram atratividade por estéticas musicais próprias, como a conservação do suingue e a alteração de harmonias e melodias (Website, Pagode Salvador, 2009). As diversas influências musicais como o próprio samba de raiz, samba de roda, soul music, funk e outros e a irreverência e energia são algumas marcas das composições, que podem ou não contar com criações mais ou menos românticas (Website, Pagode Salvador, 2009) e letras positivamente aceitas pelo público que falam sobre dança, sentimentos, destacam instrumentos do pagode e outros. As sensibilidades musicais levaram o grupo às premiações nacionais e internacionais. No decorrer dos anos, o grupo manteve um estilo próximo aos grupos da fase dos anos 2000, diferentemente de outras bandas (Chagas, 2016). Em termos de estilo e sociabilidades, o grupo também representaria um perfil estético mais " $p o p$ ", em uma possível estratégia de distinção entre diferentes públicos do pagode baiano (outros públicos podem associar-se a grupos que trabalham com temas mais polêmicos em temáticas tidas como relacionadas ao machismo, vulgaridade e apologia à criminalidade, conforme Chagas, 2016). Assim, a criação e exploração de estéticas artísticas próprias foram viabilizando práticas de inovações para o grupo.

Uma marca dessa inovação (cultural) é a performance no palco, que centra no vocalista a interação

${ }^{5}$ Cultura Mix, 2016. Disponível em: https://musica.culturamix.com/bandas/harmonia-do-samba. Acessado em: 10/06/2019. 
com o público (antes eram dançarinos/as), marcada por improviso, sensualidade, carisma, irreverência e cumplicidade, o que pode ou não ser acompanhada ou realizada por outros integrantes do grupo. Características estéticas do grupo, que, vistas como distintivas no conjunto de práticas do pagode até então, as destacaram como banda inovadora, conferindo-lhe práticas que foram seguidas por outros grupos. As próprias inovações no coração de sua arte - a música, (com a distinção na performance de instrumentos), trabalham alinhadamente à manutenção da identidade e essência musical com as percepções estéticas que se deseja imprimir ou valorizar do público (Figura 1). Assim, o grupo foi conseguindo manter e ampliar seu público de forma a se tornar o grupo "de pagode baiano com maior estabilidade no sucesso ao longo da carreira" (Website, Correio, 2019). Com isto, o grupo se estruturou empresarialmente por meio da produtora HS Produções, seu bloco de carnaval "Meu e Seu" (Chagas, 2016), suas festas (ou projetos) AMSM, o Melhor Réveillon do Mundo e Harmonia das Antigas (Website, Harmonia do Samba, 20196). 0 conhecimento tácito ou explícito desenvolvido destaca as práticas de empreendedorismo cultural do grupo no campo musical do pagode. Uma cultura de inovação (cultural) e diversificação de produtos vai se instaurando na cotidianidade de suas produções e imbricando-se no ritmo cultural da cidade.

Embora o primeiro CD tivesse sido gravado oficialmente em 1999 (Chagas, 2016) pela gravadora Abril Music (Website, Cultura Mix, 2016), o grupo musical teria alcançado o sucesso em Salvador por volta de 1998 através do auxílio de gravações piratas dos áudios de seus shows, sendo favorecidas pelo contexto cultural de então. Mesmo que isso fosse comum aos grupos de pagode neste período, um possível risco à rentabilização do grupo transformou-se em oportunidade quando o consideramos aliado às inovações culturais do grupo e à promoção boca-a-boca no âmbito popular, havendo ampliação do seu alcance. Ainda assim, o sucesso midiático nacional teria ocorrido com o acesso formal às redes nacionais de rádio e televisão (Chagas, 2016).

Modos de empreender. A criação de AMSM e sua expansão são exemplos de práticas empreendedoras, com modos específicos na formatação de produtos e que dizem sobre o contexto musical de Salvador. No verão baiano, auge para o consumo local e nacional, os ensaios são práticas de grupos musicais com apresentações relacionadas aos dias da semana (práticas, portanto, isomórficas, conforme DiMaggio \& Powel, 2005). Para o Harmonia, ter o próprio ensaio era mais que um sonho (Diário de campo, 2018), mas uma necessidade consciente para alcançar uma inserção bem-sucedida no cenário musical local. Era um importante passo para a carreira.

Segundo participantes do grupo musical, a escolha do dia da segunda-feira para a realização regular de seus ensaios foi guiada por dúvidas e preocupações éticas para não entrar em conflito com os dias de ensaios de outros grupos musicais. A reflexão quanto ao dia fez parte das preocupações do grupo, mas contou com a decisão do vocalista: "alguns ficaram na dúvida, outros apoiaram e eu dei a martelada final" (Diário de campo, 2018). 0 desejo de empreender o ensaio foi protagonizado pelo vocalista. Para além da narrativa do grupo, evidenciamos uma forma de aproveitamento de ocasiões disponíveis. 0 desejo, acompanhado pelo cálculo do não confronto, denuncia, além de habilidades relacionais com o cenário musical mais amplo, um saber relacionado a potencialização de seu público, evitando um desagrado concorrencial. Diante disto, o vocalista manifesta uma confiança em seu relacionamento com o público para a decisão: "se o povo gosta do nosso grupo, ele nos segue em qualquer dia da semana" (Diário de campo, 2018). Esta confiança é percebida, pois, mesmo sendo dias incomuns para a realização de eventos em Salvador, a escolha da segunda-feira se desdobrou em sucesso, sendo "algo que o Brasil inteiro almeja, os artistas do país inteiro comentam" (Diário de campo, 2018).

Essa prática do grupo, por mais que isomórfica, manifesta uma ousadia criativa tendo em vista os parâmetros contextuais locais e as diferentes sociabilidades exercidas nos diferentes dias da semana de Salvador. A escolha da segunda-feira - considerada como uma inovação cultural - foi reforçada pelo vocalista ao criar um bordão: "você vai ver hoje aqui, então, a melhor segunda-feira do mundo! E se prepare, porque amanhã, você vai viver a pior terça-feira do mundo" (Diário de campo, 2018), em referência ao desgaste físico do público no dia seguinte ao evento. A segunda é considerada a "melhor" segunda e os ensaios conseguiram instaurar-se em outras cidades do Brasil em outras épocas do ano. Temse a expansão de uma prática contextual local em outros momentos e sociabilidades, mantendo-se ainda assim a característica identitária da segunda-feira.

Sensibilidade. As narrativas históricas do grupo expressam um caráter sensitivo relacionado aos

${ }^{6}$ Harmonia do Samba, 2019. Disponível em: http://harmoniadosamba.com.br/\#projetos. Acessado em: 10/06/2019. 
estímulos tanto em decisões na manutenção do percurso artístico frente aos desafios iniciais, quanto relacionados à criação e manutenção de projetos e ao expressar o desafio da carga de trabalho intensa, principalmente no verão baiano. No início do grupo, alguns dos principais desafios foram de ordem financeira: os ganhos eram lentos, mas a vontade ou o desejo de continuar foi determinante. Ao expressar as certezas nas decisões durante a carreira, o vocalista as relaciona com o compromisso em seguir 'honestidades' do grupo, "de seu coração": "Somos felizes porque fazemos o que gostamos, com quem gostamos e para quem amamos" (Website, Ibahia, 20137). Há um orgulho do grupo em manter-se íntegro no decorrer dos tempos, em ter insistido e mantido sua música "do seu jeito". Isto rendeu o sucesso do grupo, em um "sentimento que transcende qualquer explicação" (Website, Ibahia, 2013). Quanto ao público, o cuidado para a satisfação de seu gosto é tido como a maior ambição do grupo (Website Ibahia, 2013). As sensibilidades orientam as ações e são as suas finalidades.

As relações de produção e consumo são marcadas assim, pelas questões estéticas, com o uso oportuno de identidade (vista em valores de familiaridade, coesão, afeto, carinho, intimidade), criação e inovação, mas também pelas questões políticas (Certeau, 2011, 2012, 2013), com o senso oportuno, relacional e intencional das ações. As características sensorialmente distintivas e que conduzem a juízos estéticos do grupo colocam-se diferencialmente a outros grupos e estéticas do pagode (algumas polêmicas), encaminhando-o para um estilo intimista, afetivo e politicamente destacado no campo musical do pagode.

Dentro do público que aprecia o pagode, são associados ao grupo Harmonia do Samba as expressões "pagode raiz", "nutella", "pagode elite”, em formas de demonstrações do senso estético popular sobre o grupo e algumas vezes, em contraposição aos grupos considerados "gueto", "baixo astral". Enquanto a palavra raiz estaria associada à autenticidade, antiguidade; Nutella estaria associada ao "gourmet", ou à flexibilização, sofisticação, inovação. Já "pagode elite" e "gueto" referem-se à aderência em diferentes grupos sociais e são geralmente usadas em oposição, e a expressão baixo astral refere-se a estéticas tidas como vulgares, polêmicas. Esteticamente, estas classificações podem ser associadas à juízos do belo, feio ou gracioso (Strati, 2007b) e levam à reflexão sobre a criação de valor entre arte e consumo. As discussões das categorias e juízos estéticos e a definição do que é belo ou bom ou não na música depende assim de tradições das sonoridades locais.

No ano de 2018, foi lançada a música e vídeo "Respeite" (Figura 1), acompanhada de um clip gravado na rua da Glória ${ }^{8}$ (bairro de Capelinha). A música promove trechos de músicas famosas do grupo e o vídeo expõe sua história comparando o passado ao estágio atual da carreira. Esta criação musical é um exemplo do uso estético da memória afetiva e musical relacionada ao bairro, da imagem estética do belo e juízo do belo associado à positividade do sucesso na progressão da carreira. Assim, a narrativa histórica e valores do grupo integram-se à estética de sua arte, promovendo práticas empreendedoras no cotidiano.

\subsection{Práticas Festivas dos Ensaios de Verão}

Os ensaios são rituais, como "usinas de criação da estética musical na Bahia do século XX" (Godi, 2005, p.3). Eles participam da construção histórico-cultural da cidade com importantes efeitos para a construção plural da música baiana e de seu contexto de empreendedorismo. Os ensaios têm singular importância para os grupos de pagode, pois ajudam na preparação para o carnaval. Embora o termo 'ensaio' signifique algo preliminar, experimental e preparatório, que antecede uma apresentação pública, em Salvador, houve uma apropriação local diferenciada do termo. Os ensaios se colocam como apresentações públicas de produtos acabados, que se situam discursivamente como antecedentes, motivadores e habilitadores para o carnaval. Operam como "vitrine de composições e compositores emergentes", onde "artistas e autores apresentam e experimentam suas músicas, em busca de legitimação popular" (Castro, 2011, p.203). Esteticamente, os ensaios podem ser 'superproduções', cuidadosas, com escolha de convidados, divulgação como megaevento e de espaços concorridos com grandes estruturas (Jornal A Tarde, 12/11/2007), transmitindo ideias de grandiosidade e beleza. Nos ensaios, os grupos apresentam lançamentos artísticos e medem sua aceitação com o público. São momentos de relacionamentos entre artistas e parcerias diversas com ganhos recíprocos. São espaços para inovações, anúncios

\footnotetext{
7 Ibahia, 2013. Disponível em: https://www.ibahia.com/detalhe/noticia/especial-20-anos-do-harmonia-conheca-a-historiapor-tras-da-maior-banda-de-pagode-da-bahia/. Acessado em: 10/06/2019.

${ }_{8}$ Música: Respeite (Harmonia do Samba): Assista em: https://www.youtube.com/watch?v=hsUCF7PNpCM. Acessado em: $18 / 12 / 2018$
} 
de blocos 'sem corda' (gratuitamente) no carnaval, permuta de cantores de grupos (Jornal A Tarde, $12 / 11 / 2007)$.

Os ensaios se concentram, geralmente, no primeiro mês do ano. Essa concentração está inscrita no calendário semanal da cidade, promovendo identificação social entre dias da semana e os grupos que neles se apresentam. Nos tempos e espaços da cidade, algumas combinações são tradicionais: nos domingos, o grupo afro 'Timbalada' (desde 1992), nas segundas-feiras o grupo 'Harmonia do Samba' (desse 2002) e o grupo afro 'Cortejo Afro' (desde 1999), nas terças-feiras a 'Terça da benção' do grupo afro 'Olodum' (desde 1989), nas quintas-feiras o grupo Psirico com o 'Ensaio do Psi' (desde 2002). Ao criar seu próprio ensaio, AMSM, o grupo Harmonia do Samba estabeleceu um espaço identitário relacionado a temporalidade da segunda-feira dentre os grupos de pagode. São apropriações inovadoras de espaço-tempo que constituem uma ordem cultural, simbólica e estratégica para o grupo. Essa apropriação permite legitimar posições dentro do campo musical dos grupos musicais locais.

Ter o próprio ensaio em um dia da semana garante ao grupo posição privilegiada. São momentos oportunos ao empreendedorismo, com um clima mais propício a este fazer, aproveitados (verão em Salvador) e criados (a apropriação espacial e temporal de dias da semana). Trata-se de uma ordem que foi criada historicamente e reproduzida por determinados grupos que conseguem instaurar uma organização própria e relativa aos seus graus de performance. Essa prática reforça práticas locais, que, por sua vez, são criadas e estimulam novas criatividades, insumos importantes para um fazer artístico cultural que se contrapõe ao global. São práticas táticas que hora confrontam criativamente espaços ou ordens (mudando lógicas racionalizantes e de forma oportuna), hora seguem ordens dominantes por meio de um poder, de práticas estratégicas, em um caráter político do cotidiano (Certeau, 2013). Um cotidiano empreendedor emerge no uso da criatividade na apropriação e improviso dentro de um senso político.

Os grupos musicais organizadores dos ensaios selecionam as participações feitas em parcerias artísticas, dependendo cada vez mais da capacidade de promover diversidade musical dentro de seus shows, atraindo cantores de sucesso que, por sua vez, atraem novos públicos. Este estabelecimento de parcerias com demais artistas desdobra-se em participações na gravação de DVDs.

A prática dos ensaios expressa um contexto espaço-temporal local (o verão em Salvador tanto leva turistas para a cidade quanto aprimora os usos culturais da cidade pelo próprio baiano que legitima e reconhece este período como propício para as festas) que é oportunamente aproveitado para o empreendedorismo musical. Explicita-se um entrelaçamento institucional que vai do local ao global, imbricando-se por fim, com o fenômeno do carnaval. As parcerias com os artistas (locais e nacionais) e outros agentes (setor privado e público local) refletem a ação empreendedora que se sustenta em construções artísticas legitimadas por reconhecimento e pertença, em uma comunidade criativa que extrapola os limites do local.

Durante a prática dos ensaios, tem-se, assim, uma prática esteticamente empreendedora que é construída social e sensualmente, gerando um produto diferente do que se espera de artistas da música. Em empreendedorismo cultural há discussões que envolvem especificidades de conhecimentos empresariais, cenários de dependência de recursos públicos e outros advindos de tensões entre arte e negócios (Ellmeier, 2003), questões pertinentes ao restrito espaço do próprio mercado artístico, as dificuldades de inserção musical, os gostos do público, a concorrência com demais grupos e estilos e escolhas da indústria (Wilson \& Stokes, 2002). A prática empreendedora dos ensaios oferta alternativas a estes pontos, colocando-se como uma inovação cultural pertinente à cultura musical baiana.

\subsection{A Prática Festiva da AMSM}

Às 20 h do dia 22 de janeiro de 2018, os portões se abriram para acesso ao público. Na área externa, carros estacionavam e o público era recebido por vendedores de vagas de estacionamento, ingressos, alimentos e bebidas. $\mathrm{O}$ som de músicas vinha de carros que começavam a chegar. $\mathrm{Na}$ área interna, um amplo estacionamento introduzia um espaço grandioso de acesso restrito. Dentro desta área, encontramos muitos bares, estruturas de banheiros, lanchonetes e telões. Estes artefatos não humanos do espaço transmitem a ideia de grandiosidade, conforto e beleza, além de preparo para a recepção de amplo público.

Um grande espaço para o público incluía um enorme palco ao fundo, seguido de camarotes nas laterais. Uma saída de emergência, marcada por grandes portões vermelhos, se colocava na lateral direita do espaço. Alguns balões presos à cabos e iluminados com informações promocionais eram vistos no cenário visual mais alto da festa. Os seguranças se colocavam presentes para a revista do público que 
passava pela entrada e pela porta dos camarotes. Outros funcionários revezavam-se na limpeza, venda ou produção no espaço.

Às $21 \mathrm{~h}$, o palco se acendeu totalmente para o início das apresentações, marcada pela ação promocional de uma rádio apoiadora. A partir daí, iniciaram-se as apresentações de artistas convidados do dia: o cantor Manu Valter acompanhou as participações do cantor Dan Valente e do locutor Lajotinha. No ano de 2018, as quatro edições da temporada de AMSM contou com participações de cantores bemsucedidos na contemporaneidade do evento como Anitta, Thiaguinho, Luan Santana e outros. Os ingressos podiam ser comprados para duas áreas (pista e área VIP, conforme Website, Ibahia, 201899).

Por volta das $23 \mathrm{~h}$, a pesquisadora se dirigiu ao camarim do vocalista para acompanhar sua entrevista à imprensa. No back stage, muitas pessoas disputavam espaços nos corredores, dentre convidados, produção, imprensa e outros. No camarim, flores, uma mesa com um farto buffet, um sofá, uma mesinha de centro, um tapete, espelhos e cadeiras, além da decoração do show com o back drop promocional, deixavam o local confortável e receptivo. Lá, o vocalista Xanddy, a empresária, artista e esposa, Carla, três produtores, três convidadas da família do cantor e duas equipes da imprensa revezaram-se nas entrevistas. Essa dinâmica terminou por voltas das $24 \mathrm{~h}$.

Em torno deste horário, o grupo Aviões do Forró se apresentava, seguido do grupo Fit dance. Estes shows, apesar de entreterem o público, dispunham de diferenças quanto ao show principal. A principal delas era o estilo musical: não eram grupos de pagode mas sim grupos marcados pelo ritmo da vaquejada, do forró eletrônico e até música pop eletrônica (Manu Valter performou também como DJ). As sonoridades e ritmos que imprimiam aos corpos eram diferentes. Embora instigassem o movimento, outras partes do corpo e sensações eram despertadas. Eram ritmos relacionados aos pés ou corpo e as letras eram mais narrativas e levavam a pensar nas histórias cantadas. As luzes do palco nestas apresentações eram marcadas por tons mais azulados (ou mais frios), na maior parte do tempo. Os demais integrantes dos grupos, posicionados mais internamente ao palco, quase não podiam ser vistos pelo público.

Apenas às $1 \mathrm{~h} 25$, do dia 23, o grupo Harmonia do Samba sobe ao palco. 0 grupo entrou vestido de branco e foi recebido com muitos gritos de excitação e euforia da plateia. Coletivos de pessoas dançavam coreografias diversas. No meio do palco, o grupo e os back vocals apresentavam-se com a participação momentânea de jovens dançarinos(as).

Fumaça, jogos de luzes e sons animavam o cenário (Figura 2), enquanto o público bebia, conversava, dançava e tirava fotos. Os corpos passaram a vibrar ao ritmo das melodias do pagode. Flertes, olhares, paqueras, puxões de mão e elogios ao pé do ouvido eram manifestações do público. Uma fã, turista que vinha de São Paulo e estava com seus filhos, elogiou a limpeza, a organização e segurança do evento e da cidade. Apenas em dado momento da festa, maior tensão foi sentida quando um grupo de homens andava em bloco entre o público e alguns tentavam apalpar objetos pessoais de outros, o que abria espaços com olhares de desconfiança, avisos e receio no público em volta. Dirigiram-se em direção ao palco, o maior aglomerado de pessoas.

0 vocalista, carismático, vivendo sua performance, empreendia passos, rebolava, cantava e suava como não suaram os artistas anteriores; ele se movimentava de forma mais entregue, hora coreografada hora improvisada. Esse momento marcou diferenças quanto às participações de outros grupos. A postura do vocalista do Harmonia era íntima, próxima e seus movimentos corporais não eram contidos como eram os movimentos dos artistas convidados. Xanddy colocava-se de forma mais convidativa, entregue. Destacava-se o movimento hora dos quadris, hora dos pés. 0 artista expressava diferentes expressões faciais e olhares com a plateia, como se brincasse, constantemente, com ela. Isto envolvia os diferentes usos do microfone, a depender do que fazia com seu corpo. As luzes do palco ficaram com tons mais alaranjados (ou mais quentes) e evidenciavam de forma mais clara todo o grupo, seus sorrisos e interações entre eles, plateia e vocalista, como se o grupo estivesse mais próximo do público. Dançarinos(as) jovens entravam com coreografias para performar com o vocalista, sendo também instigados com brincadeiras e conversas. Tudo levava ao movimento corporal vibrante e prendia a atenção ao palco.

Figura 2: 0 Público e o Palco da Apresentação da MSFA (2018)

${ }_{9}^{9}$ Ibahia, 2018. Disponível em: https://www.ibahia.com/verao/detalhe/noticia/a-melhor-segunda-feira-do-mundo-ja-temingressos-a-venda-veja-valores/. Acessado em: 10/06/2019. 


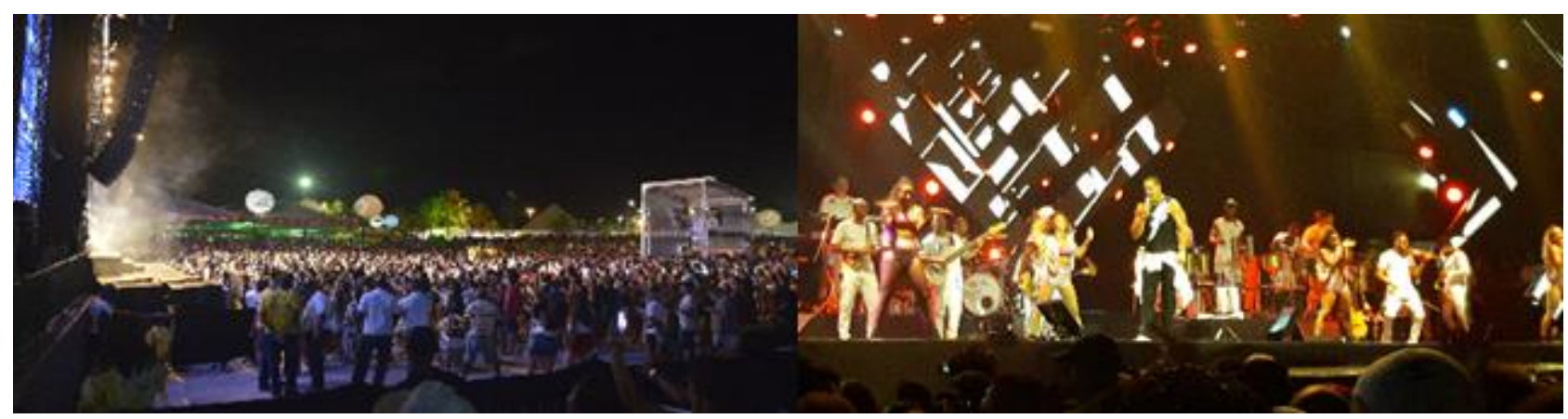

Fonte: Informações da Pesquisa

Na plateia, muitos casais ou grupos de amigos dançavam, incessantemente, e se divertiam juntos. Muitos eram os movimentos coreografados. De hora ou outra, grupos na plateia desciam rebolando até o chão. 0 cheiro de cerveja ou outras bebidas alcoólicas ficava mais intenso com o passar do tempo e o chão ficava mais molhado por bebidas derramadas. Esbarrões e toques eram frequentes. Durante sua apresentação, o grupo recebeu as participações de cantores Alexandre Pires, Saulo e Dilsinho, sempre regado a várias brincadeiras e estímulos do vocalista do Harmonia. 0 show terminou por volta das $5 \mathrm{~h}$ da manhã. Pela manhã, as pessoas manifestavam o quanto estavam cansadas, referenciando o bordão do cantor sobre "a pior terça-feira do mundo" (Diário de campo, 2018).

Relações e modos do fazer empreendedor. 0 relacionamento com a imprensa é uma prática do cotidiano artístico, que, nesta análise, evidencia não apenas uma oportunidade para promover a ação empreendedora final, que é o ensaio, mas formas de realizar micro-ações empreendedoras. Micro-ações que oportunamente aproveitam momentos relacionais para criar micro-estímulos de consumo, por meio de saberes do grupo musical, aliados aos saberes das interações e que se colocam como estímulos adequados à estética organizacional que se deseja atingir. É ainda o aproveitamento, o uso, de uma estética compartilhada para maximizar ações. É, portanto, um uso criativo e político da estética para estimular, a finalidade maior que é a prática empreendedora do ensaio. Evidenciamos um fluxo cotidiano de empreendedorismo que compõe a ação final do ensaio, que se desenvolve, corporal e relacionalmente, a partir da estética organizacional do grupo.

Por exemplo, durante uma entrevista no camarim, quando um repórter provoca o vocalista falando de desafios para chegar ao evento naquele dia (engarrafamento, dia de segunda-feira), representando percepções do público, o vocalista afirma que está "tudo lindo" (em referência à estar tudo bem e a festa estar organizada): "tudo lindo", você vai ver hoje, aqui, a melhor segunda-feira do mundo! E se prepare, porque amanhã, você vai viver a pior terça-feira do mundo!” (Diário de campo, 2018). 0 bordão é usado para valorizar a segunda-feira ao mesmo que é vinculado à irreverência no saber de que há um desgaste do público no dia seguinte. Mas, ainda assim, é positivo, tendo em vista o prazer proporcionado pela festa. Esta sensação prazerosa aparece nas palavras "tudo lindo" (a beleza usada analogamente à organização), "a melhor" e a "pior" (valorizações por adjetivações opostas e extremas positivas e negativas, demonstrando diferentes intensidades do sentir, assim como o uso da expressão "do mundo", relacionada à grandeza do evento). Na relação da oportunidade sugerida pelo repórter (trazendo e representando vivências de público em sua fala) e no uso apropriado do vocalista do bordão já previamente criado e cotidianamente praticado no jogo de saberes que envolvem elementos temporais e estéticos, expressa-se carisma e sensualidade, estimulando e compartilhando sentimentos com o público.

0 prazer e "compartilhar esse prazer com outros praticantes é algo que é aprendido e ensinado [...] através da elaboração coletiva de um léxico compartilhado para comunicar sentimentos sensíveis" e estes são julgamentos estéticos que sustentam práticas sociais e geram vínculo (Gherardi, 2013, p.114) nas relações envolvidas. A orientação do gosto estimula a criatividade, intimamente ligada aos costumes locais por estas formas de expressão cultural (Frith, Cloonan \& Williamson, 2009). Há uma micro-ação empreendedora desenvolvida na relação cotidiana e caracterizada pelo uso oportuno (momento da fala) da criatividade (bordão) no estímulo ao público (o apelo estético). Esta prática promocional é desenvolvida por estes modos de ação (micro-empreendedores) que aparentam uma espontaneidade, mas são repletos de saberes tácitos e empáticos. São saberes desenvolvidos ao longo da carreira e que se colocam também na base de improvisos culturais. 
Um exemplo de improviso que sustenta os saberes e o uso da estética corporal do vocalista (carisma, sensualidade, irreverência, gentileza) é uma brincadeira que o vocalista faz com outro repórter no camarim. Ao fim da entrevista, já com as ações promocionais realizadas, o vocalista pega os óculos do repórter e balança como se estivesse hipnotizando (em referência a uma das principais músicas de trabalho daquele ano) e pede: "sua obrigação é trazer pelo menos 5 mil pessoas na segunda que vem" (Diário de campo, 2018). 0 vocalista usa uma composição artística do momento de forma irreverente e sensual na interação com uma parte importante no seu cotidiano profissional (imprensa), para pedir público. Em um trocadilho artístico, a arte é usada, oportunamente, com um parceiro por meio de saberes para uma ação, aparentemente imprevista. É uma ação que faz parte de estratégias sensuais e carismáticas do vocalista, articulando seus saberes tácitos e sua arte ao cotidiano de relação sensível com parceiros e público.

Esta articulação de ações oportunas, irreverentes, sensuais e intencionais com parceiros de negócios envolvidos em uma finalidade promocional, situa-se como criação cultural dentro de uma microação empreendedora (porque contribui para a promoção do ensaio). Ela manifesta um fazer empreendedor na prática artística: a possibilidade de uso da própria estética artística para sensibilizar agentes envolvidos na ação empreendedora, a arte para uma sensibilização empreendedora.

No camarim, as relações eram expressas no revezamento de sorrisos, brincadeiras e movimentos corporais animados, dentro de um clima de irreverência ou em olhares centrados e diretos, com gestuais corporais e falas mais pausadas, toques sensuais ou delicados a depender do conteúdo da fala. Eram interações pautadas pelos juízos estéticos (lindo, gostoso, melhor, pior, maior), demonstração de sensações e comparações estéticas que contagiavam todos naquela coletividade, conforme expressões corporais em resposta aos estímulos do cantor.

Figura 3: Vida Pessoal e Profissional Imbricada na Prática Empreendedora

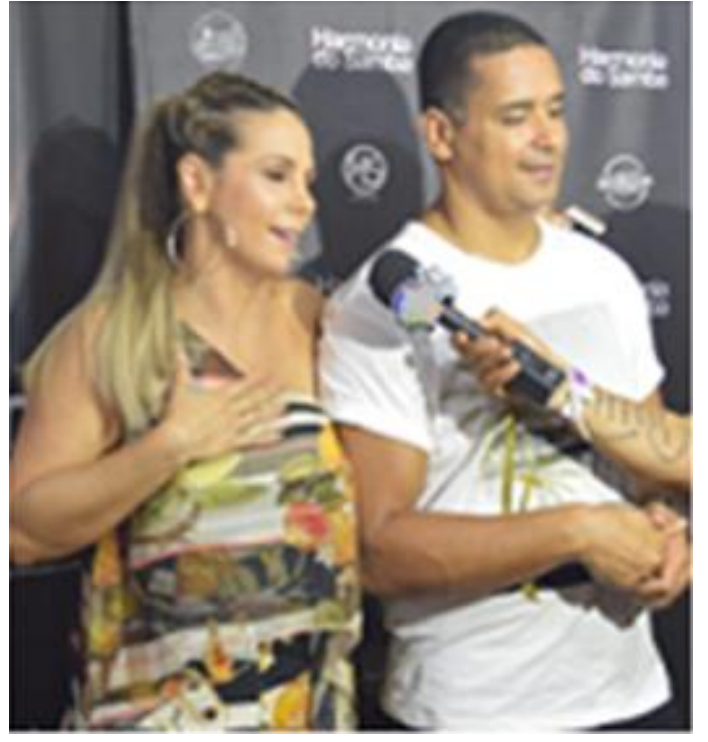

Fonte: Informações da Pesquisa

Na entrevista no camarim, o vocalista enfatiza os shows em outras regiões: "Fizemos no Rio de Janeiro, fizemos em Natal, fizemos em São Paulo... em Vitória" (Diário de campo, 2018). 0 vocalista usa o espaço de entrevistas para promover o carinho, as sensações e novos shows, o que ocorre também ao anunciar novidades para o Carnaval como a gratuidade de blocos direcionado às crianças. Isto envolve ações da família do vocalista incluindo sua esposa (cantor a chama para participar ativamente da conversa, conforme Figura 3), e filha também iniciada na música. São esforços de colaboração e rede pessoal para uma mobilização cotidiana do empreendedorismo. É na intensa promoção do grupo por valores familiares, imbricados em estéticas nas relações com o público, que a prática do empreendedorismo cultural vai acontecendo.

A preocupação com a carreira é explicitada em uma narrativa estética que valoriza o passado, os esforços contínuos de crescimento, as conquistas presentes e ações futuras: "a Bahia sabe que era pequenininho, que foi crescendo [...] e hoje é esse negócio enorme [...] Ou você começa aos pouquinhos, bem devagar [...] ou você enfrenta um desafio muito grande" (Diário de campo, 2018). Outra expressão 
ocorre no camarim, quando o back drop estaria mais baixo que o esperado pelo cantor. Há expectativas estéticas cobradas pelo artista à sua produção e que interferem em sua performance. São conhecimentos tácitos que, na prática, ao serem compartilhados, geram aprendizagem sobre o que é correto ou "belo". É a estética contribuindo para a aprendizagem. $O$ acesso ao capital cultural e simbólico, moldando habilidades que, ao serem percebidas, permitem observar conflitos e resolvê-los, e isto repercute em níveis de confiança e comprometimento que levam a estabilidade ou não das relações profissionais. Mais do que ações promocionais, expressam-se saberes tácitos do grupo musical que evoluem em micro-inovações na própria desenvoltura relacional com a mídia. São rituais de interação, práticas cotidianas e culturais de empreendedorismo.

No relacionamento com o público, observamos diferenças nos modos de fazer do grupo. 0 vocalista busca envolver a plateia por meio de várias referências. Ele fala do grupo como um coletivo e se refere à história da carreira. Usando a expressão "família Harmonia", ele promove valores identitários e estimula sentimentos por ações, palavras e melodias. Evocam-se valores como a tradição e a religiosidade ("são tantos anos que eu fico me questionando, Deus, será que merecemos tudo isso?", conforme Diário de campo, 2018) em uma manifestação gentil de gratidão. As narrativas remetem à sentimentos compartilhados com o público e estendem a gratidão, publicamente, aos artistas convidados: "é muito carinho, é uma energia, é um negócio que às vezes me intriga muito. Eu quero agradecer a todos vocês, a cada um que sai de suas casas. Nós temos um time [artistas convidados] que reforça, que faz a galera sair de casa" (Diário de campo, 2018).

0 vocalista mobiliza a memória: "são quase 20 anos, a gente se encontrando; tem gente aqui que era criança", e faz evocações empáticas: "na nossa segunda, é como se a gente tivesse na sala de casa. Eu me sinto assim com vocês" (Diário de campo, 2018) para criar percepções afetivas e familiares de vínculo com o público. Ao fazer isto, o vocalista aprofunda a densidade estética do vínculo: "Então, eu vou perguntar: qual é o nosso grau de intimidade de 0 a 10? [público responde: “10!!!”] (Diário de campo, 2018). A provocação do grau de intimidade é uma criação, contada pelo vocalista no camarim com euforia: uma criação que deu certo na interação com o público. A história do grupo, sua memória popular, evocadas por palavras que exprimem familiaridade, religiosidade, tradição e sentimentos compartilhados do grupo com o público levam à uma intimidade percebida coletivamente, em um ato envolvente: "Eu sinto muito isso, eu sinto que existe essa intimidade de verdade" (Diário de campo, 2018). 0 vocalista expressa compreensão empática e a usa no aprimoramento cotidiano de sua arte, na relação com seu público.

Em seguida, uma canção é introduza pela voz do cantor e ritmicamente seguida pelos instrumentos do grupo de forma lenta, sensual e entrosada. Este ritmo é acompanhado de novos pedidos do cantor: "Agora eu vou medir isso com expressão corporal. O que eu fizer daqui vocês precisam fazer daí" (Diário de campo, 2018). 0 cantor estimula o público a agir sensualmente como ele, alinhando seus ritmos corporais na performance corporal da música que diz: "Foi só te ver, pra me apaixonar, fui pro Harmonia e você estava lá" (Figura 4).

A música e a dança provocam a intimidade, dentro de um clima de catarse, que se expressa em letra apropriada para a intimidade do momento. Isso tudo envolve a ação do olhar, o sentir (paixão), e a presença (corpórea) do grupo na narração de uma história romântica presente na canção. Tem-se um momento de romantismo que envolve o grupo e seu público, alinhados oportunamente entre discurso, canção e ritmos compartilhados. Trata-se de um ritmo que transmite a sensação de unidade e leva a aproximação entre grupo e público, dentro de uma união estética na experiência da sensação. São auges do entretenimento, uma evocação envolvente. São convivências evocativas, convites do grupo para criar momentos compartilhados que se tornam sensivelmente marcantes e são embalados pela estética romântica da canção. Tem-se o uso artístico (música e dança), embalado por discurso intimista, criando uma narração e novos sentidos à música e sua memória. Cria-se uma memória estética. São novos sentidos atribuídos à narrativa, ou seja, novas narrativas de narrativas da arte. Novas criações que envolvem mais do que o som tocado nas rádios ou playlists de celulares, mas o visual, o movimento e o corporal participativo, a troca. É a criação de novas experiências por meio de novas sensações. São novas performances artísticas vividas. Cria-se ou reforça-se uma comunidade de práticas sensoriais.

Figura 4: Apresentação Musical em uma AMSM (2018) 


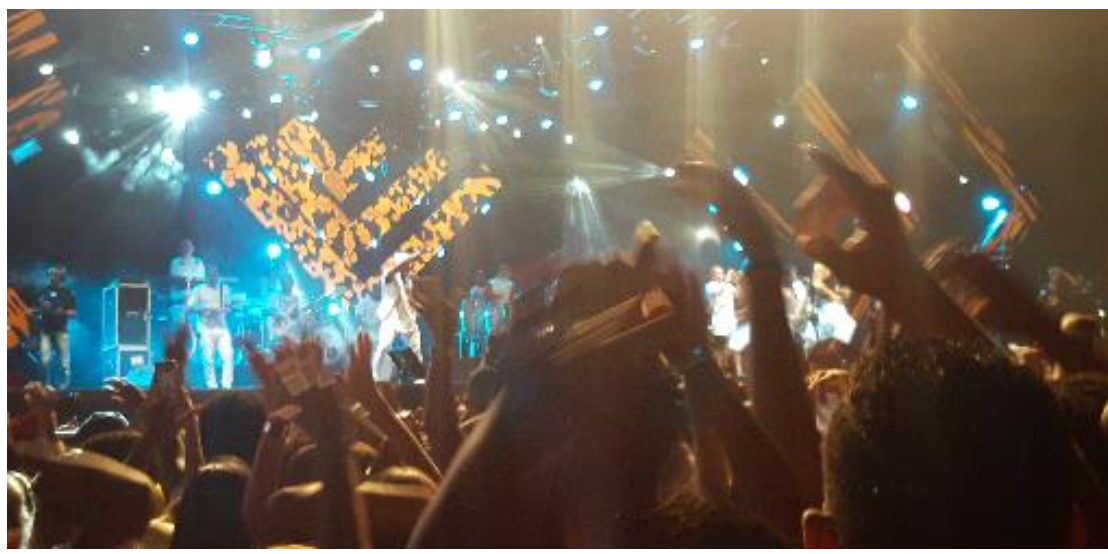

Fonte: Informações da Pesquisa

O público passa a dispor de um destino para viver determinadas experiências, experiências sensoriais (sensuais), irreverentes, corpóreas, coletivas e íntimas. 0 vocalista e seu grupo se expressam como evocadores de sensações pela música e pela performance ativamente alimentadas na interação com o público. $O$ público se torna um participante ativo nesta interação, tendo sua importância na ação, esteticamente exaltada. Tem-se aqui um empreendedorismo na criação momentânea de novas sensações (e narrativas), com a evocação e o engajamento de sentimentos do e com o público, a co-criação de valor cultural e estético. É a estética sendo e contribuindo para o envolvimento. São sensações vividas e específicas àquela experiência, portanto sempre diferenciadas, por serem também singulares. A estética contribuindo para a inovação. Esta forma momentaneamente criativa, oportuna e multisensorialmente (Pink, 2015) compartilhada de fazer, este desejo de comunicar (Scherdin \& Zander, 2011), ao mesmo tempo em que expressa uma capacidade de persuasão da arte (Scherdin \& Zander, 2011) cativa um público que busca permanentemente consumir estas sensações.

A caraterística inclusiva na criação resvala-se em outro produto, os álbuns. 0 artista cita cobranças explícitas por parte dos fãs e lhes confere méritos como co-criadores de seus CD’s: “o povo de Salvador estava cobrando. Eu digo: espera aí! Vamos arrumar um jeito desse povo se sentir um pouquinho dono desse negócio na gravação do DVD" (Diário de campo, 2018). Além disso, os investimentos intimistas do grupo resvalam-se em narrativas de um público cativo, a "torcida". Uma fã contou que se tratava de uma síndrome do pânico, mas que, pela afetividade com o grupo, acompanhando-o desde que tocavam no bairro de Capelinha, teria decidido ir ao show, aceitando encarar multidões após alguns meses de reclusão. “Ontem, nós fizemos o espetáculo ‘Harmonia das Antigas' em Recife. Fizemos o 'Fest Verão' anteontem [...] todo mundo lá com a gente [...] a coisa mais linda do mundo" (Diário de campo, 2018).

Uma preocupação do grupo volta-se para a renovação, valorizando públicos mais jovens: "Depois de tantos anos, é tão bom a gente com esse ar novo, esse ar de juventude. Vamos aproveitar esse clima, essa atmosfera gostosa de novidade, do povo curtindo, inclusive muita gente jovem, crianças, adolescentes, mandando mensagens. Muitos conhecendo o Harmonia" (Diário de campo, 2018). A preocupação com a diversidade de público incorpora-se à estética do grupo, com uso intensivo de juízos estéticos, direcionados à públicos específicos: "[quando] nos passam mensagem de carinho [...] é tão gostoso, é tão bom" (Diário de campo, 2018). "Tantos anos", "tão bom", "novo", "novidade", "juventude", "atmosfera gostosa" são expressões que intensificam a estética do empreendimento cultural do grupo. Todas as sensações compartilhadas entre público e grupo operam como combustível para o próprio cotidiano e fazer empreendedor frente a um ritmo de trabalho extenuante: "A gente está numa correria danada. Está frenético! Mas, está gostoso! A gente gosta assim. Verão é isso mesmo!" (Diário de campo, 2018).

A prática cotidiana do ensaio expressa micro empreendedorismos que são esteticamente relacionais. Dentro de um percurso biográfico, o ensaio reforça o trabalho identitário do grupo e permite a negociação dentro do campo da música na Bahia. Há um senso oportuno de aproveitamento de situações contextuais que contribuem com o desenvolvimento do grupo, gerando projeção diferenciada e oportunizando uma organização de suas práticas. Neste sentido, as performances artísticas parecem se confundir com performances empreendedoras em uma ideia de estética como estratégia. A indicação de uma estética como uma estratégia de distinção, semelhança e criação apoia a decisão de forma esteticamente política. As criações aparecem, oportunamente, tanto na performance artística quanto empreen- 
dedora, em uma sociabilidade amparada no sentir e em um saber-fazer cotidiano. Juízos estéticos dispõem, assim, de destaque e influência diferencial em ações de empreendedorismo, fundamentando estes juízos. Por mais que toda experiência tenha uma dimensão estética (Dewey, 1950), tem-se a estética como diferencial ao fazer parte do cotidiano usual do campo e sendo oportunamente usada.

As ações são aqui julgadas, esteticamente, sobretudo pelas faculdades sensoriais da audição e da visão, assim como pelas faculdades corporais do tato. Essa diversidade estética possibilita uma ampla liberdade de escolhas nas práticas musicais (envolvendo a sociabilidade e a organização dos shows), na composição das músicas e coreografias e na preparação destes. A maneira como estes elementos são articulados diferencialmente e atendem ao perfil estético do consumo resulta em inovação. Neste sentido, a estética também leva a observar a ética e a política nas relações entre diferenças, semelhanças e intenções.

Em síntese, foi possível observar por estas narrativas, práticas estéticas empreendedoras relacionais tanto na criação de produtos musicais quanto festivos.

\section{Empreendedorismo como Prática: Perspectivas, Contextos e Desafios}

As práticas empreendedoras do grupo musical 'Harmonia do Samba' nos permitem elaborar e discutir sobre perspectivas, contextos e desafios para a pesquisa em empreendedorismo. Três perspectivas podem ser propostas e discutidas: a lente do cotidiano, da inovação e da estética para pesquisar o empreendedorismo como prática. Dois contextos emergem do campo cultural e artístico: o contexto da prática estética e da prática festiva. Por fim, os desafios teóricos e metodológicos podem ser elencados e refletidos.

A primeira perspectiva proposta é a da lente do cotidiano para aprofundar o estudo do empreendedorismo como prática. No cotidiano, há um fluxo contínuo de micro-ações que alinham saberes tácitos e conhecimentos explícitos em movimentos que integram tanto a ação individual quanto relacional, inserida em um contexto cultural de práticas. Saberes tácitos e conhecimentos explícitos resgatam a história para mobilizar valores que compõem senso identitário. 0 senso identitário contribui para identificar a estética em uma comunidade de práticas. Esta estética por sua vez, (a) orienta as práticas empreendedoras na maior ou menor negociação (daí o caráter político) com outras estéticas (tendo em vista que a estética pode ou não significar o compartilhamento de significados com diferentes intensidades com determinados grupos), e (b) explica diferenças nos protagonismos em uma comunidade de praticantes empreendedores. 0 resultado da negociação estética pode ser inovador e gerar empreendedorismos. Assim, o empreendedorismo como prática é um fenômeno individual e relacional, contextual, identitário, sensorial, político. Na lente do cotidiano, isto significa a calibragem da análise dos modos de ação por questões estéticas e como elas se desdobram em negociação para criar valor e percepção compartilhados.

A segunda perspectiva refere-se a lente da criação como cultura do cotidiano. Quando vislumbramos o empreendedorismo como prática, a criação que move o processo empreendedor é inscrita na cultura do cotidiano, podendo gerar inovações. A criação resulta de elaborações compartilhadas, inscritas, oportunamente, em um contexto socioespacial cotidiano. A criação interliga-se com o senso de oportunidades diárias de duas formas: a oportunidade relacional estimula a criação (que pode ser uma inovação) e a oportunidade relacional fixa a criação, contextualmente, podendo transformá-la em outra prática que se interliga à formatação de empreendedorismos cotidianos, a depender de seus usos. Assim, o senso de oportunidade tanto estimula criações quanto as aprimoram, as refinam ou as colocam sob novas criações, quando às reforça no oportuno uso de determinado tempo e espaço, de determinadas ocasiões.

Além disso, a criação resulta da negociação no cotidiano de aspectos identitários e estéticos (alia saberes, valores e percepções estéticas do grupo com a estética percebida do público ao grupo) e se desdobra em variadas formas de apresentação, como improvisos relacionais, produtos incrementais ou inovadores. Estes produtos estão fortemente associados ao contexto cultural por estas formas, aqui evidenciadas como estéticas, de ligação. A inovação na cultura do cotidiano considera a relação entre estética e cultura como força motriz para a ação inovadora, entendendo melhor como isto ocorre em um contexto oportuno e relacional e como os saberes, aprendizagens e percepções são mobilizadas. Diante das criações, mais corriqueiras, a inovação aparenta, no cotidiano, maior caráter de excepcionalidade, ou seja, ocorre com menor frequência no tempo. Ainda assim, estaria diretamente associada às características do espaço, do que é ou não inovador naquela cultura musical e artística. 
A terceira perspectiva que emerge desta pesquisa é, portanto, a lente da estética como cultura do cotidiano empreendedor. Nesse processo, incluir os conhecimentos de estética organizacional torna-se imprescindível. A estética organizacional explora o conhecimento sensível, uma forma de saber e agir percebidos e julgados por meio dos sentidos (Strati, 2007b). Já que os critérios estéticos do que é aceitável ou não são coletivamente sustentados, envolvendo uma negociação (Gherardi, 2013), a estética conduz a negociação da identidade com a cultura para gerar inovações no meio cultural. Evidenciamos, assim, o componente sensível da compreensão da ação intencional organizacional e empreendedora (Strati, 2007a). A cultura oferta como premissa diferentes vias de se praticar o empreendedorismo.

0 enfoque empírico da pesquisa no campo cultural e artístico destaca dois contextos fecundos para a pesquisa futura: o contexto da prática estética e da prática festiva. 0 contexto da prática estética refere-se ao fato de que no empreendedorismo musical em estudos, a atividade empreendedora mistura-se com atividade estética. Com isso, a dimensão estética encontra-se intensificada. Estes fatores, no campo cultural, expressam subjetividades artísticas, empreendidas não apenas no fazer artístico, mas também imbuídos nos próprios fazeres organizacionais, que estimulam as ações empreendedoras em diversos resultados, seja criação, improvisação, manutenção ou expansão. Tornam o fazer organizacional, também artístico. Esse contexto abre caminho para pesquisas futuras que buscam compreender a relação entre empreendedores culturais e como eles sustentam gostos, paixões e sentimentos que, por sua vez, estimulam criatividades, improvisações e os enquadram politicamente em dada realidade social.

O contexto da prática festiva é revelado pelo enfoque no campo cultural e artístico da música. Não há festa sem música, mas a prática festiva é um contexto empírico ainda pouco estudado em relação ao empreendedorismo. Festas não são apenas práticas sociais da música, mas empreendedorismos que formam organizações, principalmente, pela oportunidade, no contexto econômico e estético contemporâneo, tanto das mudanças tecnológicas ocorridas na indústria fonográfica quanto das novas necessidades experiências do consumo, que levam à novas demandas em performances artísticas. Compreender como o mundo artístico se estrutura, empreendedoramente, em práticas de festas, revela um caminho promissor para pesquisas futuras.

Para enfrentar os novos encaminhamentos da pesquisa sobre empreendedorismo como prática, pelo menos, dois desafios se colocam. 0 primeiro desafio é de natureza teórica. Como a ancoragem teórica para estudar a prática é plural e variada, a escolha e integração de abordagens diversas pode ser um desafio para o pesquisador. A própria característica da permanente construção e conexão entre praticantes e práticas, a não delimitação e descrição totalmente objetivas das práticas, a especificidade de sentido pertinente ao campo onde se processam as práticas e a necessidade de observação não apenas da linguagem, mas da dimensão sociomaterial, ética e estética das práticas (Gherardi, 2013) são desafios conceituais do campo do empreendedorismo, aprimorados ainda pela vivência social acomodada em lentes individualistas e economicistas tradicionais do campo.

O segundo desafio de pesquisa é de natureza metodológica. Para estudar a riqueza e sutileza que a prática empreendedora supõe, torna-se necessário um alinhamento metodológico para fazer da observação participante e sistemática um mecanismo primordial durante o processo de pesquisa. Neste sentido, tanto aportes metodológicos do campo da prática, muitos advindos da sociologia, quanto àqueles que se alinham à suas especificidades, quanto os estéticos, requerem empenho de pesquisadores em desenvolver uma prática sensível de observação, dentro de campos corpóreos e sensoriais, com ênfase na busca antropológica de exploração dos sentidos.

Em suma, pensar o empreendedorismo cultural como prática significa valorizar o fenômeno processual, relacional, social, estético, emocional, tácito, ético, político e substantivo, permitindo ao pesquisador observar a influência das materialidades, simbolismos, sentimentos e juízos, aprendizagens e conhecimentos, formas de organização, tensões cotidianas, uma vez que as práticas são locus da aprendizagem (Gherardi, 2013) e unificam o saber com o fazer em uma ocorrência social (Gherardi, 2006).

\section{Conclusão}

O objetivo deste estudo foi ampliar, consolidar e discutir a compreensão do empreendedorismo a partir dos EBP. Para isto, realizamos uma pesquisa teórico-empírica, aplicando os EBP no contexto empírico de um empreendedorismo cultural do campo da música. Os resultados da pesquisa contribuem para aproximar os EBP dos estudos sobre empreendedorismo cultural, ampliando e consolidando nossa compreensão do empreendedorismo como prática. Nesse sentido, contribuem para entendermos como 
o conhecimento prático se manifesta em um empreendedorismo do setor musical. Um campo empírico que enfoca a festa como espaço de empreendedorismo cultural, por isso, essa também pode ser considerada uma contribuição indireta desta pesquisa.

No âmbito metodológico, a pesquisa oferece alternativas ao individualismo metodológico, quando foca na coletividade, observando como esta coletividade conforma ações individuais dando luz à novas contribuições ao campo do empreendedorismo. Alguns estudos em empreendedorismo parecem narrar o que se pesquisa a partir de uma visão individualista. Nossa pesquisa contribui ao provocar uma reflexão sobre formas de análise que abordam o relacional e o social.

Colocamos a visão de que o empreendedorismo como prática precisa ser mais problematizada à luz do cotidiano que as teorias da prática trazem. Neste sentido, estudar outros campos não tradicionais ao estudo do empreendedorismo podem ajudar, porque dispõem de uma visão menos conformada sobre o fenômeno. A contribuição dos EBP é promissora pois proporciona uma ruptura com as principais formas de compreender o empreendedorismo como um profundo e sensível processo sociocultural.

\section{Agradecimento}

Agradecemos o apoio do CNPq (Conselho Nacional de Desenvolvimento Científico e Tecnológico, $\left.\mathrm{n}^{\circ} 400190 / 2016-8\right)$ e sugestões enriquecedoras dos avaliadores.

\section{Referências}

Baia, S. F (2011). A historiografia da música popular no Brasil (1971-1999). São Paulo: Departamento de História, Faculdade de Filosofia, Letras e Ciências Humanas, Universidade de São Paulo (tese de doutorado).

Banks, M., Gill, R. \& Taylor, S. (2014). Theorizing Cultural Work. Labour, Continuity and Change in the Cultural and Creative Industries. Abingdon: Routledge.

Banks, M., Lovatt, A., Connor, J. O., \& Raffo, C. (2000). Risk and trust in the cultural industries. Geoforum, 31(4), 453-464.

Borges, A. F.; Brito, M. \& Lima, J.B. (2016). Entrepreneuring: Conceiving the Phenomenon of Entrepreneurship as a Practice. XL Encontro da Anpad. Bahia.

Borges, A. F.; Lima, J. B. \& Silvestre, J. (2018). Empreendedorismo como prática: o caso de uma organização produtora de cachaça artesanal. XXI Semead. São Paulo.

Bureau, s. \& Zander, I (2014). Entrepreneurship as an art of subversion. Scandinavian Journal of Management, 30(1), p. 124-133.

Busenitz, L. W., Plummer, L. A., Klotz, A. C., Shahzad, A., \& Rhoads, K. (2014). Entrepreneurship Research (1985-2009) and the Emergence of Opportunities. Entrepreneurship Theory and Practice, 38(5), 9811000.

Busenitz, L.W., West, G.P., Shepherd, D., Nelson, T., Chandler, G.N., \& Zacharakis, A. (2003). Entrepreneurship research in emergence: Past trends and future directions. Journal of Management, 29, 285308.

Castro, A. A. (2011). Axé Music: Mitos, Verdades e World Music. In: A larga barra da baía: essa província no contexto do mundo [online]. Salvador: EDUFBA. p. 242-237.

Certeau, M. (2013). A invenção do cotidiano: artes de fazer. Petrópolis, RJ: Vozes, p.322.

Certeau, M. (2012). A cultura no plural. Campinas, SP: Papirus, p.253.

Certeau, M. (2011). A invenção do cotidiano: morar; cozinhar. Petrópolis, RJ: Vozes, p.322.

Chagas, L. (2016). Corpo, Dança e letras: Um Estudo Sobre a Cena Musical do Pagode Baiano e suas Mediações. Salvador, Universidade Federal da Bahia, Instituto de Humanidades, Artes e Ciências Professor Milton Santos (dissertação de mestrado).

Cook, S. D. N., \& Brown, J. S. (1999). Bridging Epistemologies: The Generative Dance Between Organizational Knowledge and Organizational Knowing. Organization Science, 10(4), 381-400.

Corradi, G.; Gherardi, S. \& Verzelloni, L. (2010). Through the practice lens: where is the bandwagon of practice-based studies heading? Management Learning, 41(3), p. 265-283.

Davel, E.P.B. \& Cora, M. A. J. (2016). Empreendedorismo cultural cultura como discurso, criação e consumo simbólico. Políticas Culturais em Revista. 9, p. 363-397.

De Clercq. D. \& Voronov, M. (2014). Toward a Practice Perspective of Entrepreneurship: Entrepreneurial Legitimacy as Habitus. International Small Business Journal, 27(4), p. 395-419.

Dewey, J. (1950). Aesthetic Experience as a Primary Phase and as an Artistic Development. The Journal 
of Aesthetics and Art Criticism, 9(1), 56-58.

DiMaggio, P. \& Powell, W. (2005), "A gaiola de ferro revisitada: isomorfismo institucional e racionalidade coletiva nos campos organizacionais", Revista de Administração de Empresas, 45(2). p. 74-89.

Elias, S. R. S. T. A. et al. (2018). The Aesthetics of Entrepreneurship: How Arts Entrepreneurs and their Customers Co-create Aesthetic Value. Organization Studies, 39(2-3), p. 345-372.

Ellmeier, A. (2003). Cultural Enterpreneurialism: on the changing relationship between the arts, culture and employment. International Journal of Cultural Policy, 9(1), p. 1-15.

Feldman, M. S. \& Orlikowski, W. J. (2011). Theorizing Practice and Practicing Theory. Organization Science, 22(5), p. 1240-1253.

Fachin, F. F., \& Davel, E. (2015). Reconciling contradictory paths: identity play and work in a career transition. Journal of Organizational Change Management, 28(3), 396-392.

Feldman, M. S., \& Orlikowski, W. J. (2011). Theorizing Practice and Practicing Theory. Organization Science, 22(5), 1240-1253.

Frith, S.; Cloonan, M. \& Williamson, J. On music as a creative industry. In: Pratt, A. C. e Jeffcutt, P. (Ed.). (2009) Creativity, Innovation and the Cultural Economy. London: Routledge.

Gagliardi, P. (2006). Exploring the Aesthetic Side of Organizational Life. In T. S. Clegg, C. Hardy (Ed.), The Sage Handbook of Organization Studies (pp. 701-724).

Gartner, W. B. et al. (2016). Entrepreneurship as practice: grounding contemporary practice theory into entrepreneurship studies. Entrepreneurship \& Regional Development, 28(9-10), p. 813-816.

Gherardi, S. (2013). Prática? É uma Questão de Gosto! Revista Interdisciplinar de Gestão Social, 2(1), p. 107-124.

Gherardi, S (2006). Organizational Knowledge: The Texture of Workplace Learning. Oxford: Blackwell Publishing.

Gherardi, S., Nicolini, D., Strati, A. (2007). The Passion for Knowing. Organization, 14(3), 315-329.

Godi, A (2005). Performance Afro-Musical: Legitimação e Pertencimento no Contexto Eletrônico. Disponível em: http://www.videobrasil.org.br/pan africana/ENSAIO GODI.pdf. Acessado em: 24/06/2018.

Goss, D., Jones, R., Betta, M., \& Latham, J. (2011). Power as practice: A micro-sociological analysis of the dynamics of emancipatory entrepreneurship. Organization Studies, 32(2), p. 211-229.

Gubrium, J. F., \& Holstein, J. A. (2009). Analyzing narrative reality. Thousand Oaks: Sage Publications.

Guerra, J. R. F., \& Paiva Júnior, F. G. d. (2014). O Empreendedorismo no Campo da Produção Cultural: analisando a dimensão privada da ação empreendedora no audiovisual. Revista Livre de Cinema, 1(2), 55-73.

Guerreiro Ramos, A. (1989). A nova ciência das organizações: uma reconceituação da riqueza das nações. São Paulo: Editora da FGV.

Hartley, J., Wen, W., \& Li, H. S. (2015). Creative Economy and Culture: Challenges, Changes and Futures for the Creative Industries. Los Angeles: Sage Publications.

Henry, C., \& Bruin, A. d. (Eds.). (2011). Entrepreneurship and the creative economy: process, practice and policy. Cheltenham: Edward Elgar.

Hjorth, D. \& Steyaert, C. (Ed.) (2009). The politics and aesthetics of entrepreneurship. Cheltenham: Edward Elgar.

Hjorth, D. (2003). Rewriting Entrepreneurship: for a new perspective on organisational creativity. Copenhagen: Copenhagen Business School Press.

Hjorth, D. (2013). Absolutely fabulous! Fabulation and organization-creation in processes of becomingentrepreneur. Society and Business Review, 8, 205-224.

Hockey, J., \& Allen-Collinson, J. (2009). The sensorium at work: the sensory phenomenology of the working body. The Sociological Review, 2(52), 217-239.

Johannisson, B. (2011). Towards a practice theory of entrepreneuring. Small Business Economics, 36(2), p. $135-150$.

Jones, C., Lorenzen, M., \& Sapsed, J. (Eds.). (2015). The Oxford Handbook of Creative Industries. Oxford: Oxford University Press.

Khaire, M. (2017). Culture and Commerce: the Value of Entrepreneurship in Creative Industries. Stanford: Stanford University Press.

Klamer, A. (2011). Cultural entrepreneurship. Review of Austrian Economics, 24(2), p. 141-156.

Lash, S., \& Urry, J. (1994). Economies of signs and space. London: Sage Publications.

Latour, B. (1994). Jamais fomos modernos. São Paulo: Editora 34. 
Lave, j.; Wenger, E. (1991). Situated Learning: Legitimate Peripheral Participation. Cambridge: Cambridge University Press.

Lawrence, \& W. Nord (Eds.), The SAGE handbook of organization studies (pp. 701-725). London, UK: SAGE Publications.

Leme, M. N. (2003). Breve inventário da "vertente maliciosa" na história da música popular no Brasil. São Paulo: Annablume.

Lindqvist, K. (2011). Artist entrepreneurs. In: Scherdin, M.; Zander, I. (Ed.). Art entrepreneurship. Cheltenham: Edward Elgar Publishing.

Lingo, E. L., \& Tepper, S. J. (2013). Looking Back, Looking Forward: Arts-Based Careers and Creative Work. Work and Occupations, 40(4), 337-363.

Maitlis, S. (2012). Narrative analysis. In G. Symon \& C. Cassell (Eds.), Qualitative organizational research: core methods and current challenges. Los Angeles: Sage Publications.

Moura, M. (1996). Esses pagodes impertinentes: algumas reflexões sobre o sofisticado e o vulgar no âmbito da música popular em Salvador. Textos de Cultura e Comunicação. Salvador. FACOM. UFBA n.36, p.53-66.

Nicolini, D. (2009). Zooming In and Out: Studying Practices by Switching Theoretical Lenses and Trailing Connections. Organization Studies, 30(12), 1391-1418.

Nicolini, D.; Gherardi, S. \& Yanow, D. (2003). Knowing in organizations: a practicebased approach. New York: M. E. Sharpe.

Oliveira, M. C. \& Campos, M. DE F. H. (2016). Carnaval, Identidade Negra e Axé Music em Salvador na Segunda Metade do Século XX. Textos escolhidos de cultura e arte populares (TECAP), 13(2), p. 70-84.

Orlikowski, W. J. (2002). Knowing in practice: enacting a collective capability in distributed organizing. Organization Science, 13(3), p.249-273.

Paiva Júnior, F. G. d., Guerra, J. R. F., \& Almeida, S. L. d. (2012). A Dimensão Pública da Ação do Empreendedor Cultural na Produção de Cinema. Cadernos de Estudos Sociais, 27(1), 155-170.

Pink, S. (2015). Doing sensory ethnography. London: Sage Publications. 2nd.

Polanyi, K., (2012). A subsistência do homem - e ensaios correlatos, Rio de Janeiro, Contraponto.

Preece, S. B. (2011). Performing Arts Entrepreneurship: Toward a Research Agenda. The Journal of Arts Management, Law, and Society, 41(2), 103-120.

Rentschler, R. (2007). Painting equality: female artists as cultural entrepreneurial marketers. Equal Opportunities International, 26(7), p. 665-677.

Riessman, C. K. (2008). Narrative Methods for the human sciences. Los Angeles: Sage Publications.

Sarasvathy, S. (2001). Toward Causation and Effectuation: A Theoritical Shift From Inevitability to Economic Entrepreneurial Contingency. The Academy of Management Review, 26(2), p. 243-263.

Schatzki, T. R. (2006). On organizations as they happen. Organization Studies, 27(12), p. 1863-1873. Schatzki, T. R. (2001). Introduction: practice theory. In: Schatzi, T. R.; Knorr-Cetina, K.; Savigny, E. Von. The Practice Turn in Contemporary Theory. London: Routledge.

Schatzki, T.R., Knorr-cetina, K. \& Von Savigny, E. (2001). The Practice Turn in Contemporary Theory. London: Routledge.

Scherdin, M. \& Zander, I. (2011). Art entrepreneurship. Cheltenham: Edward Elgar Publishing Limited. Shane, S. \& Venkataraman, S. (2001). Entrepreneurship as a field of research: A response to Zahra and Dess, Singh, and Erikson. Academy of Management Review, 26, 13-16.

Schildt, H.A., Zahra, S.A., \& Sillanpaa, A. (2006). Scholarly communities in entrepreneurship research: A co-citation analysis. Entrepreneurship Theory and Practice, 30, 399-415.

Souza, M. B. D. (2015). Mexe o balaio: um olhar sobre o pagode baiano. Prelúdios, 4(4), p. 123-135.

Spilling, O. R. (1996). The Entrepreneurial System: On Entrepreneurship in the Context of a Mega-Event. Norwegan School of Management, n. 36, p. 91-103.

Spink, M. J. (Org.). (2004). Práticas discursivas e produção de sentidos no cotidiano: aproximações teóricas e metodológicas. São Paulo: Cortez.

Steyaert, C. (2007). "Entrepreneuring" as a conceptual attractor? A review of process theories in 20 years of entrepreneurship studies. Entrepreneurship and Regional Development, 19(6), p. 453-477.

Steyaert, C., \& Hjorth, D. (2003). Creative movements of entrepreneurship. In C. Steyaert \& D. Hjorth (Eds.), New movements in entrepreneurship. Cheltenham: Edward Elgar Publishing.

Steyaert, C., \& Katz, J. (2004). Reclaiming the space of entrepreneurship in society: Geographical, discursive and social dimensions. Entrepreneurship and Regional Development, 16(3), 179-196. 
Strati, A. (2009). 'Do you do beautiful things?': Aesthetics and art in qualitative methods of organization studies. In D. Buchanan \& A. Bryman (Eds.), Handbook of organizational research methods (pp. 230245). London, UK: SAGE Publications.

Strati, A. (2007a). Sensible Knowlodge and Practice Based Learning. Management Learnirng, 38(1), p. 61-77.

Strati. A. (2007b). Organização e Estética. Rio de Janeiro: Editora FGV.

Taylor, S. S., \& Hansen, H. (2005). Finding form: Looking at the field of organizational aesthetics. Journal of Management Studies, 42(6), 1211-1231.

Terjesen, S. \& Elam, A. (2009). Transnational Entrepreneurs' Venture Internationalization Strategies: A Practice Theory Approach. Entrepreneurship Theory and Practice, 33(5), p. 1093-1120.

Vale, G. M. V. (2014). Empreendedor: Origens, Concepções Teóricas, Dispersão e Integração. Revista de Administração Contemporânea, 18(6), 874-89.

Van Maanen, J. (1988). Tales of the field: on writing ethnography. Chicago: University of Chicago Press. Watson, T. J. (2013). Entrepreneurship in action: Bringing together the individual, organizational and institutional dimensions of entrepreneurial action. Entrepreneurship and Regional Development, 25(56), p. 404-422.

Vogt, S., Bulgacov, Y. L. M., \& Elias, S. R. S. T. A. (2019). Entrepreneurial Learning in Practice: Fragments of Aesthetic-Sensible Knowledge in Entrepreneurs' Life Trajectory. Paper presented at the 4th Annual Entrepreneurship as Practice Conference, Nantes, France.

Vogt, S., \& Bulgacov, Y. L. M. (2018). Aprender, Empreender e Aprender: a Perspectiva da Prática para o Entendimento do Processo da Aprendizagem Empreendedora. Revista Da Micro e Pequena Empresa, 12(3), 28-43.

Werthes, D.; Mauer, R. \& Brettel. M. (2017). Cultural and creative entrepreneurs: understanding the role of entrepreneurial identity. International Journal of Entrepreneurial Behavior and Research, 24(1), p. 290-314.

Wilson, N., \& Stokes, D. (2002). Cultural entrepreneurs and creating exchange. Journal of Research in Marketing Entrepreneurship, 4(2), 37-52. 